CONSUMER EXPENDITURES AND HOME

Production at Retirement - New

EVIDENCE FROM GERMANY

Melanie Lührmann

๑ mea-Mannheim Research Institute for the Economics of Aging

L13, 17_D-68131 Mannheim_Phone +49 621 181-2773/1862_Fax +49 621 181-1863_www.mea.uni-mannheim.de 


\title{
Consumer Expenditures and Home Production at Retirement - New Evidence from Germany*
}

\author{
Melanie Lührmann ${ }^{\dagger}$
}

March 30, 2007

\begin{abstract}
This paper investigates consumer expenditures of German households pre- and post-retirement. The widely observed distinct drop in spending upon retirement entry poses an empirical puzzle since life cycle theory predicts smoothing of the marginal utility of consumption over time. As one explanation, I explore the role of home production as a substitute for consumer expenses. Taking a combined look at consumer expenditures and time use pre and post-retirement, I find a significant drop of about $17 \%$ of pre-retirement expenses at retirement which coincides with an increase in time spent on home production of an additional $33 \%$ per day.
\end{abstract}

Keywords: Consumer Demand, Time Use, Retirement, Life Cycle Model JEL Classification: D12, D13, D91, J26

*I thank Axel Börsch-Supan, Karsten Hank, Florian Heiss, Alexander Ludwig, Matthias Weiss and Joachim Winter for inspiring discussions and helpful comments on this paper. Fabian Terner provided excellent research assistance. Funding by the State Baden-Württemberg, the Gesamtverband der Deutschen Versicherungswirtschaft, and the EU Research Training Network Microdata Methods and Practice is gratefully acknowledged. The usual disclaimer applies.

${ }^{\dagger}$ Centre for Microdata Methods and Practice, and Institute for Fiscal Studies. 7, Ridgmount Street, London WC1E 7AE. Phone: 0044207 2914804, Email: m.luhrmann@ifs.org.uk 


\section{Introduction}

This paper investigates whether consumer expenditures change around retirement in Germany and whether this is accompanied by changes in home production. A distinct drop in spending around retirement has already been documented for other countries like the US, Italy and the UK. It constitutes the so-called retirement consumption puzzle because standard life cycle theory predicts that forward-looking agents with concave utility functions smooth consumption over time, such that no drop is to be expected. Various reasons have been put forward in the literature to solve this puzzle and to reconcile observed behavior with the life cycle theory. They range from unexpected health and income shocks around retirement, cessation of work-related costs, non-separability between consumption and leisure to substitutional home production.

This paper contributes to the literature by presenting evidence on the magnitude of the drop in expenditures in Germany based on a large repeated crosssectional sample. Additionally, I analyze the role of home production in explaining this empirical puzzle. Home production has mostly been investigated by looking at expenditure categories like household services which can be substituted by home production. Disproportionate expenditure drops in these categories have been attributed to increased home production activities. This interpretation cannot be separated from disproportionate expenditure cuts on some commodities that are not compensated by increases in home production. Combining the analysis of expenditure data with time use data, I can draw direct conclusions about the home production activities of retirees and non retirees, and whether they complement the observed drop in spending. Furthermore, I can decompose home production into separate activities and thus investigate substitutional behaviour at a very disaggregated level.

Using the German expenditure survey (Einkommens- und Verbrauchsstichprobe, henceforth: EVS) over the period 1978-1998, I find a significant one-off drop in nondurable consumer expenses at retirement which is comparable to those found for the US, Italy and the UK. I investigate this drop in a multivariate regression analysis controlling for differences in household characteristics of retired and not retired households ${ }^{1}$, and for age and cohort effects using the DeatonPaxson decomposition. The results point to a $17 \%$ drop in nondurable spending which varies across age groups. Furthermore, the analysis shows that the drop is discontinuous and levels off partially during retirement.

Additionally, I use two waves of the German time use survey (Zeitbudgeterhebung) from the years 1991/92 and 2001/02 to investigate whether this drop is compensated by increased home production. This explanation for the puzzle bases on the notion that consumption does not equal expenditures. If households

\footnotetext{
${ }^{1}$ For simplicity, I use the terms "households with a retired head" and "retired households" synonymously throughout the paper.
} 
engage to a considerable degree in producing goods and services themselves, they can consume more than just their market purchased goods and services. The analysis of the time use patterns shows that households with a retired head spend 82 minutes per day more on home production activities than non-retired ones. I also identify the specific activities that retired households engage in: they are cooking and preparing meals, paperwork and - arguably in part a leisure activity - gardening.

The remainder of the paper is organized as follows: First, I give an overview over the literature addressing the retirement consumption puzzle (Section 2). Next, I describe the data (Section 3). Third, I produce some basic facts about retirement behavior in Germany and a descriptive analysis consumption and home production around retirement (Section 4). Section 5 presents the results of the multivariate analysis and additional results for special home production activities. Section 6 concludes.

\section{Literature review}

The life cycle model predicts that rational forward-looking agents make their savings decisions such that consumption is smoothed over the life cycle (Modigliani and Brumberg 1954). In spite of several extensions of the life cycle model which comprise uncertainty about the length of life, precautionary savings motives, and bequest motives, the model has been challenged by empirical studies showing that US and British households reduce their consumer expenditures significantly upon entry into retirement (Banks et al. 1998; Hurd and Rohwedder 2005; Miniaci et al. 2003; Smith 2004; Aguiar and Hurst 2005). Bernheim et al. (2001) find that $31 \%$ of US households reduce their expenses by at least 35 percentage points at retirement, while Hamermesh (1984) found that $53 \%$ of the retired couples reduced their spending by more than $10 \%$ relative to the average change in real spending between 1973 and 1975. Laitner and Silverman (2005) report the drop to amount to $16 \%$ for the US. ${ }^{2}$ This phenomenon has been termed the retirement consumption puzzle.

\subsection{Work-related costs}

Several reasons have been put forward to explain this puzzle, and to reconcile it with the life cycle theory. The first argument is the cessation of work-related expenses upon retirement. Work-related expenses consist of meals purchased out of home, adult clothing, transport costs for travelling to and from work, and expenses for domestic services. Banks et al. (1998) for the UK, Bernheim et al.

\footnotetext{
${ }^{2}$ The only contradictory evidence is provided by Christensen (2004) who finds no drop in consumption in a group of Spanish retirees for whom income does not change upon retirement, so that the income effect and the effect of additional leisure are not confounded.
} 
(2001) for the US, as well as Miniaci et al. (2003) for Italy have found that the cessation of work-related costs reduces spending in old age to some extent, but cannot explain the magnitude of the observed drop.

\subsection{Unanticipated income shocks around retirement}

A second explanation are unanticipated shocks occurring around retirement, i.e., individuals expect a larger retirement income ex ante than they receive ex post which forces them to re-optimize and adjust their expenditures downward. Banks et al. (1998) find that differential mortality risk and work-related costs, explain about two-thirds of the observed fall in consumption. Hence, the authors argue that the remaining third must be due to "unanticipated shocks occurring around the time of retirement" (p.784). ${ }^{3}$

Hurd and Rohwedder (2003) find that individuals anticipate their future spending correctly: Among singles (couples), the average anticipated drop in spending is about $20 \%$ (for both groups) compared to an actual decline of about $17 \%(12 \%)$. In a follow-up study using panel information, $59 \%$ of those retiring between the two CAMS waves anticipated a decline, yet just $46 \%$ recalled a decline. The share of respondents anticipating a decline is larger than the share reporting a decline in spending after retirement entry (Hurd and Rohwedder 2005). The relative difference between anticipations and recollections is about the same as in the cross-section, namely 13-16 percentage points of consumer expenditures.

\subsection{Unanticipated health shocks}

Another shock could be a sudden deterioration of the health status which induces a person to retire earlier than planned. Hence, they forego additional earnings and their lifetime resources are reduced. Hurd and Rohwedder (2005) exploit a question on the reasons for retiring. Among those households for whom health was an important reason (21.9\% of the sample), $68 \%$ had a decline in spending with an average magnitude of around $25 \%$. The other two-thirds of respondents who did not state health to be a retirement reason reduced spending by $11 \%$ only. The problem with this approach is that one cannot entirely separate an expected from an unexpected health deterioration. While expected health events are taken into account by life cycle planners, an unexpected event leads to a reduction in lifetime resources and a downward adjustment of consumption.

\footnotetext{
${ }^{3}$ For example, Dilnot et al. (1994) shows that $40 \%$ of the British overestimate their pension benefit entitlements.
} 


\subsection{Non-separability of consumption and leisure}

Another explanation for the retirement consumption puzzle becomes evident when generalizing the standard life cycle model to include leisure and consumption in the utility function, such that the within-period utility function is $u\left(f\left(c_{t}, l_{t}\right)\right)$. Laitner and Silverman (2005) show that there should not be a discontinuous drop in consumption growth at retirement if the utility function is separable. However, if one does not make this restrictive assumption, then the marginal utility of consumption depends on leisure. If consumption and leisure are substitutes, the marginal utility of consumption will decrease with higher leisure, such that households compensate by consuming less goods and services. This explanation would be consistent with the observed drop in consumer expenditures and the life cycle hypothesis.

\subsection{Changes in home production}

Extending the standard model framework to comprise two consumer goods, one market good and one good which can either be bought or produced at home, changes the theoretical predictions of the life cycle model. The results depend on the substitution elasticity between the consumer good and the home production good (see Laitner and Silverman 2005).

When workers retire, they have more leisure time at their disposal given constant hours spent on work at home. In consequence, their marginal utility of leisure falls, thus reducing the opportunity cost of working in home production: Retirees can make up for their reduced retirement income by producing consumer goods at home because they have substantially more (leisure) time. Additionally, households might just purchase goods less costly, e.g. by comparing prices more intensively or by shopping at more shops in search of lower prices. In the presence of such substitutional behavior, households do not reduce their consumption, but only their expenses. In a two good model, one would not expect consumer expenses to remain constant, and one would expect consumption and expenses to differ. The home production argument differs from the non-separability argument made above: If leisure time can additionally be used to produce consumer goods, the drop in consumer expenditures will be larger than the one in a model without home production.

The scope for substituting market goods by home-produced ones is large: Households can cook more at home rather than eat out, spend more time searching for good bargains in all consumer goods categories, do home cleaning and house and garden maintenance themselves, repair and wash their clothing themselves, perform simple repairs and clean their car themselves. Hurd and Rohwedder (2005) investigate whether time spent on home production changes upon retirement, and they find that it increases from 14 to roughly 20 hours per week for males aged 60-64 and from 24 to 29 hours for females. 
Aguiar and Hurst (2005) compare food spending and food intake (measured in calories or vitamins) and find no evidence of reduced consumption or a decline in food quality. They interpret their findings as evidence of a change in food production which uses less or cheaper market goods and more time. Furthermore, they find matching evidence of a $21 \%$ increase in time spent on food production for households in past-peak-retirement age 66-68 compared to pre-peak-retirement age 60-62. Thus, especially when comparing workers and retirees who have substantially different budgets of (leisure) time, consumption might be generated using strongly heterogeneous combinations of the inputs time and money.

Schwerdt (2005) studies the role of home production in Germany using panel data from the Socio-Economic Panel. He finds an expenditure drop of about $8.5 \%$ which he shows to be offset just in part by increased home production. He separates the "substitution effect" of home production by dividing the panel into a low and a high income replacement ratio group ${ }^{4}$, and finds that even individuals with no drop experience increases in home production after retirement. However, some data issues limit the scope of his study: First, only a small number of 312 retirement transitions are observed, resulting in a small sample, which is then further subdivided into two groups. Second, consumption has to be inferred as the residual of income minus savings, raising concerns about measurement error. Third, the SOEP contains information on a limited set of home production activities only.

This paper uses two large repeated cross-sectional data sets, which contain detailed expenditure and time use diary information. I construct a synthetic panel in order to filter unobserved cohort heterogeneity. Thus, it provides complementary evidence on the role of home production in explaining the expenditure drop around retirement. Furthermore, I use the detailed time use information to shed light on the specific home production activities that retirees engage in.

\section{The data}

The empirical analysis is based on two data sets: fives cross-sections of the largescale expenditure survey EVS with over 200,000 households from 1978 to 1998, and two cross-sections of the time use survey Zeitbudgeterhebung for the years 1991/92 and 2001/02, with roughly 15,000 households. In the EVS, respondents are asked to record their expenses in a housekeeping book. In the time use survey, respondents also keep a diary, but record their activities during the day for two (three) days in the 1991/92 (2001/02) survey.

The dependent variables are (i) nondurable expenditure (and its log) which I deflate by the consumer price index provided by the Statistisches Bundesamt, and (ii) time spent on home production in the household in minutes per day.

\footnotetext{
${ }^{4}$ where the replacement ratio is calculated by dividing post- and pre-retirement incomes.
} 
Home production is defined as cooking and preparing meals, washing and repairing clothes, maintenance, repairs and cleaning of house and garden, caring for children and elderly people, and shopping activities. In section 5.3, I decompose home production into these components.

\section{Descriptive evidence}

\subsection{Retirement in Germany}

The key explanatory variable in this paper, retirement status, is a dummy taking the value 1 if the household head is retired. ${ }^{5}$ Figure 1 displays the fraction of retired respondents by age in the two data sets, and shows very similar retirement patterns. $10 \%$ of the household heads are already retired at age 55, and most retirement entries are observed between ages 56 to 64 . Over $95 \%$ of respondents are retired at age 65 , and the remaining non-retirees are mainly self-employed or farmers. ${ }^{6}$

Figure 1: Retirement probability of household head: Expenditure Survey vs. Time Use data

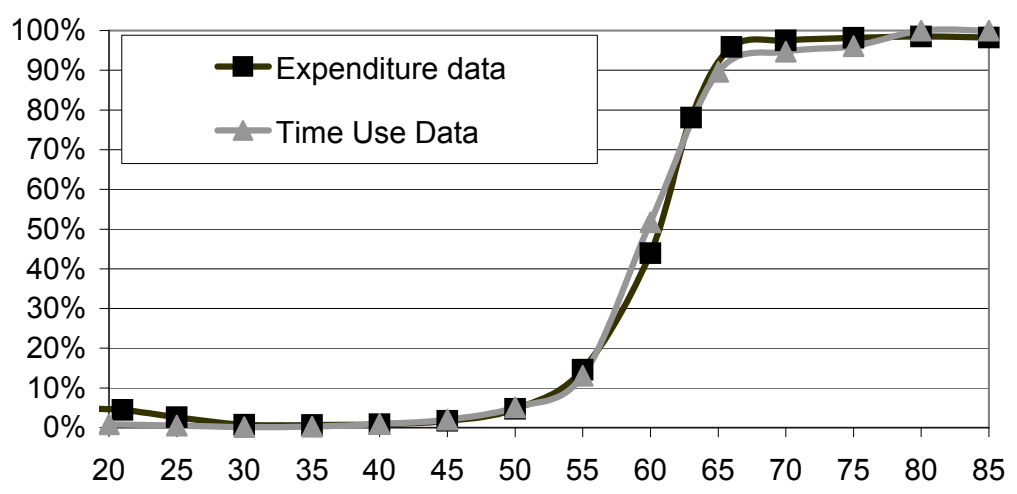

The wide age range over which people retire in Germany is due to heterogeneity in retirement incentives. For example, the statutory retirement age for women (men) was 60 (65) years until 1992. Afterwards, this differential retirement age was removed and set to 65 for both sexes. Workers with a long work history could retire already at age 63 after 1992. Additionally, generous early retirement

\footnotetext{
${ }^{5}$ In the expenditure survey, this information is based on a self-assessment of work status and a question on whether pension income is the main income source. In the time use survey, a self-rating was not available in the 2001/02 wave, so I imposed retirement on those over 65 if they were not self-employed or farmers, and unemployed or not working with a retired partner.

${ }^{6}$ These two groups face completely different retirement incentives: First, their old-age provision system is very different from that for employees. Second, they often run a family business and retire gradually or not at all.
} 
schemes were in place. For an overview of the incentive structure of the German pension system, see Berkel and Börsch-Supan (2004) and Börsch-Supan et al. (2004). Except for a few self-employed, retirement is generally completed around age 65. Unfortunately, neither the EVS nor the Zeitbudgeterhebung record any information on the work history of retired respondents. Data on contribution years, type of employment (civil servant, worker or private sector employee), or past earnings, would allow to properly model retirement timing and incentives. The lack of any instruments for the retirement probability and for retirement income limits the scope of this analysis. Given the differences between households in the timing of retirement, I decompose my results by age groups to allow for heterogeneous effects of retirement.

\subsection{Is there a consumption drop?}

The standard method of investigating consumption in repeated cross-sectional data is to construct pseudo-panels of cohorts. The underlying assumption for following cohorts over time is that survey respondents of each cohort are randomly drawn from the cohorts in the population. This method does not allow to capture unobserved individual heterogeneity, but it captures the heterogeneity of different cohorts (Deaton 2000).

Figure 2: Expenditures by age and retirement status (in 1000 DM per year)

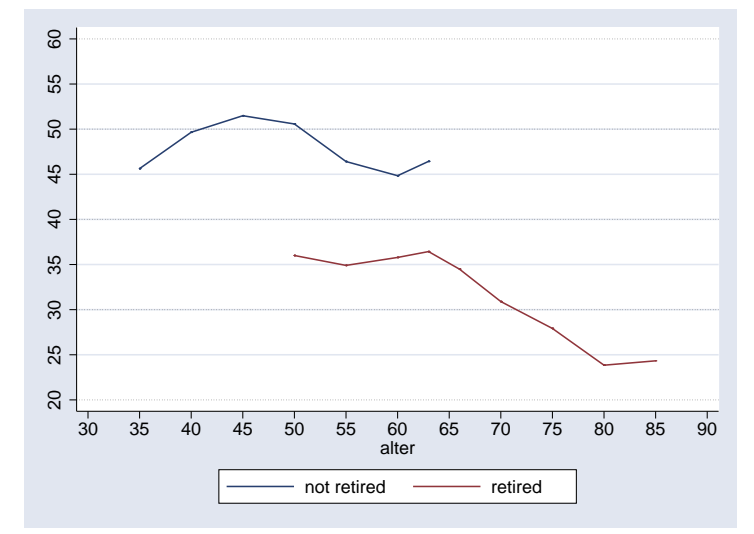

Figure 2 plots nondurable expenditures by age and retirement status, neglecting cohort heterogeneity for the moment. The results show a large drop in expenses of roughly $20 \%$ of nondurable pre-retirement spending. Furthermore, the Figure suggests that there is again a reduction in spending during the retirement phase after age 66 . The figure also suggests potential selection effects in retirement entry. The increase in spending among non-retirees beyond age 60 and the increase in spending among retirees in the same age group suggests that 
some of the wealthier households with higher expenses retire later. ${ }^{7}$ The increase of expenditures after age 80 is likely due to small cell sizes.

Figure 3: Expenditures by age, retirement status and cohort
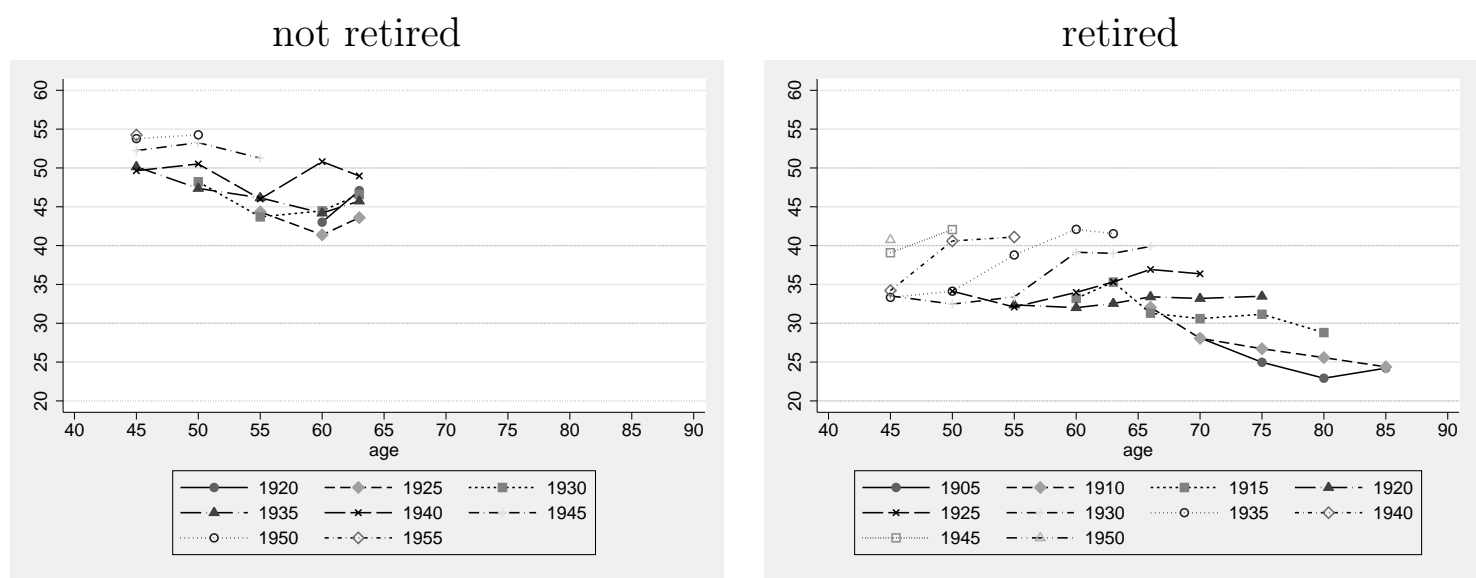

Note: Expenditures are in 1000 DM per year.

Decomposing this picture by cohort for those beyond age 45, one gets Figure 3. It shows that the observation of a spending drop is not due to cohort effects. Even when comparing retirees and non-retirees of the same cohort, there is a distinct fall in expenses. Surprisingly, the age profiles of households with a retired head are increasing for the younger retiree cohorts and decreasing for the older ones. ${ }^{8}$

\subsection{Does home production jump at retirement?}

Now I turn to the descriptive analysis of home production. Consistent with the home production argument, Figure 4 shows a large increase in the time households spend on home production after entry into retirement. The difference between households with a retired and those with a not retired head is roughly 40 minutes per day and roughly a $15 \%$ increase relative to the 270 minutes of home production that not retired households in the age group 55 do per day.

\footnotetext{
${ }^{7}$ In these figures, I plot the group of not retired households until age 65 only, because over $99 \%$ of employees are retired at age 66 .

${ }^{8}$ Alternatively, when assuming cohort effects to be zero and allowing for time effects, the drop is similarly dramatic, but the age profiles are relatively flat until age 65 and decreasing afterwards.
} 
Figure 4: Household home production time by retirement status and age

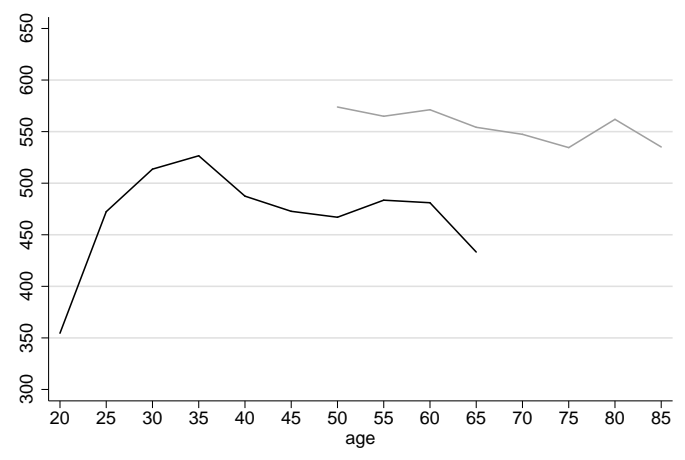

not retired $\longrightarrow$ retired

\section{$5 \quad$ Regression analysis}

In the multivariate analysis, I estimate age profiles, and additionally use retirement status and other household characteristics as regressors. In the two subsections for expenditures and for time use, I use an OLS estimator with robust standard errors. ${ }^{9}$

In order to deal with the well-known identification problem between age, cohort and time effects, I use the Deaton-Paxson approach. It assumes time effects to be zero in the long-run, thus allowing for short-run time effects like business cycles Deaton and Paxson (1994). All remaining time variation is attributed to age and cohort effects. I define age and cohort dummies in 5 year intervals, except for the age groups 60-62, 63-65, 66-69 which are defined over three year intervals. Since the Zeitbudgeterhebung has only been conducted twice, I do not have enough waves to separate age and cohort effects, so the cohort and year dummies are omitted in this part of the empirical analysis. However, in comparison to the $E V S$, a richer set of household characteristics, especially education and home ownership, can be used.

\footnotetext{
${ }^{9} \mathrm{I}$ obtain a robust variance estimator using the Huber-White-Sandwich estimator which gives heteroskedasticity-consistent standard errors.
} 


\subsection{Nondurable expenses}

In the investigation of consumer expenditures, the following empirical specification is used:

$$
\begin{aligned}
\ln x_{h} & =\sum_{c_{l}}^{c_{h}} \alpha_{c} \operatorname{coh}_{h c}+\sum_{a_{l}}^{a_{h}} \beta_{a} a g e_{h a}+\sum_{t_{l}}^{t_{h}} \gamma_{t} \text { time }_{h t}+\sum_{k=1}^{K} \eta_{k} Z_{h k} \\
& +\delta \cdot \text { ret }_{h}+\sum_{a_{l}=50}^{a_{h}=65} \zeta \cdot \text { ret }_{h} \cdot \text { age }_{h a}+\epsilon_{h t}
\end{aligned}
$$

where $x_{h}$ are log nondurable expenses of household $h$, modelled as a function of cohort, age and the transformed time dummies as well as household and other characteristics $Z .{ }^{10}$ The key variables of interest are retirement status ret, and four interacted age-retirement dummies for the age groups close to retirement.

Table 1 shows the estimation results. I start with the age-cohort profiles in column (1), augmented by the retirement dummy. Figure 5 plots the estimated age coefficients. The age profile is hump-shaped and peaks at ages 40-44.

In column (2), I add retirement status and the age-specific interactions with the retirement dummy. Overall, consumer expenses of the retired are $29 \%$ lower than the spending of not retired households. The interactive effects show that those who are retired at age 50-54 experience an even larger drop in expenditures which is significant at the $5 \%$ level. While I do not find a significant additive effect of retirement for households with a retired head in the age group 55 to 59, I find a lower impact of retirement on the age groups 60 to 65 . For these age groups, spending is only about $20 \%$ lower than that of not retired households whose head is in the same age group. However, these results are biased, as the next column (3) shows. Here, I add more household characteristics. The retirement dummy reduces to 0.17 when I control for household characteristics, but remains significantly negative. The interactive age-retirement coefficient for the age group 50 to 54 is about the same as before, and the estimated coefficient for the next age group ( 55 to 59 years) is very similar and significant. The interaction dummies for the age groups 60 to 65 become insignificant.

\footnotetext{
${ }^{10}$ Time subscripts are omitted to keep the notation simple.
} 
Figure 5: Estimated age profile of log nondurable expenditures (from column(1))

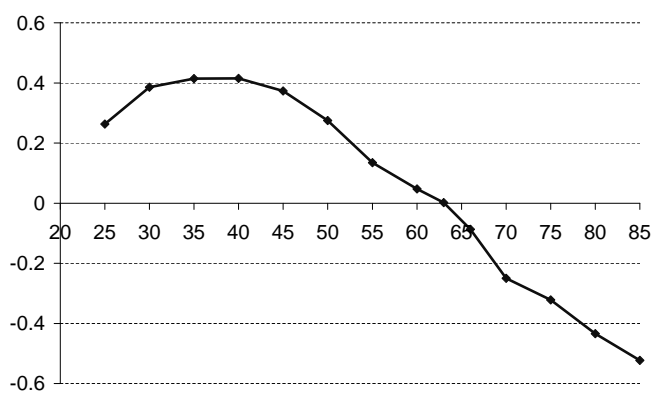

Figure 6 compares the age profiles of households with a retired head with those of households whose head is not retired. The profiles show the distinct effect of retirement on nondurable spending which is largest for the early retiring households between age 50 and 54. The drop becomes much smaller beyond age 59 .

Figure 6: Age profiles of log consumption by retirement status

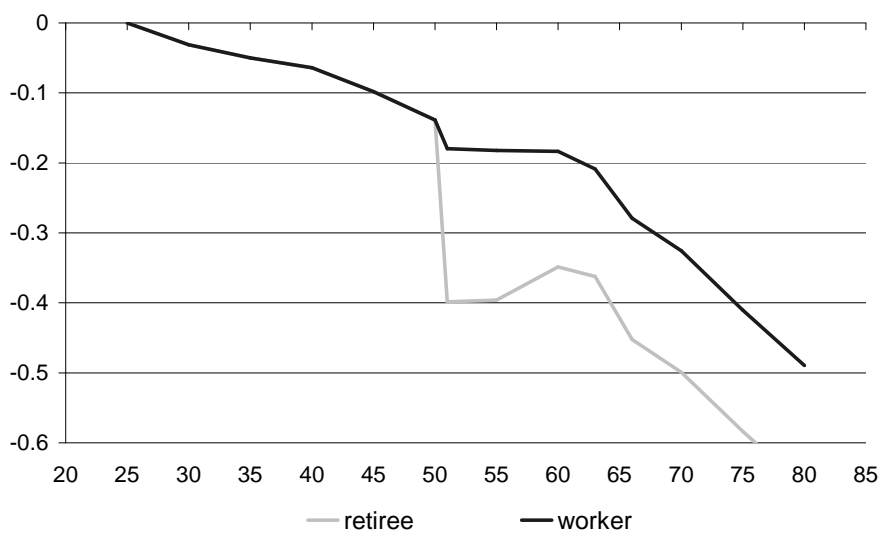

One of the additional household characteristics that are included in column (3) is household size which I measure as the log number of equivalent adults living in the household. To compute this number, I use a coarse equivalence scale where each child (adult) obtains a weight of 0.5 (1). The estimated coefficient is highly significant and positive, but with 0.43 well below unity. This implies that I cannot split up the households into individuals by using per capita expenditures. Additionally, it might also indicate that the equivalence scale is not very precise. ${ }^{11}$

Households with larger houses or apartments (measured in $m^{2}$ ) have higher spending - probably due to higher incomes or higher wealth. I include additional

\footnotetext{
${ }^{11}$ The negative significant coefficient of the number of kids might be an additional indication.
} 
controls for self-employed and farmer households because they face entirely different pension schemes and often do not retire at all or retire gradually. Selfemployed have higher nondurable spending which might be a wealth effect. The estimated coefficient for the farmer dummy, however, is significantly negative. One measurement problem in the data is that I do not observe self-employment or farmer status when households declare themselves as retired. As a robustness check, I also estimated column (3) without the self-employed and the farmer variable and the results are basically unchanged.

Another group who should have lower consumption levels are the unemployed. The lifetime resources of unemployed households are lower due to foregone earnings, such that I expect consumption to be adjusted downwards when a household experiences periods of unemployment. The significant negative coefficient points towards this hypothesis. Again, I do not observe former unemployment for households with a retired head, so I also experimented with omitting this variable - with similar results. The effect of retirement reduces to 0.14 and the counteracting effects of the interaction terms for the age groups between 60 and 65 years become larger. However, the adjusted $R^{2}$ also falls from 0.49 to 0.46 .

The other control variables indicate that couples spend more than singles, and households with a female head spend less. The latter is probably an income effect originating from the fact that many of these households are headed by widows who receive (lower) widow pensions.

Summarizing, I find a significant expenditure drop upon retirement of about $17 \%$ when I control for age and cohort effects and household characteristics. The drop is different for retired households of different age groups. It is largest for early retired households between ages 50 and 60, and lower thereafter. A caveat of this analysis is the lack of suitable instruments for strategic retirement timing of households. I partially account for the heterogeneous retirement timing by allowing for an age-specific retirement effect.

In the next section, I turn to the analysis of changes in home production time upon retirement. The underlying question is: Do retiree households really consume less or do they substitute market purchased goods in part by homeproduced ones? And if so, what do they produce at home? 
Table 1: Regression results: Consumption

\begin{tabular}{|c|c|c|c|}
\hline \multicolumn{4}{|c|}{ dependent variable: $\log$ (total nondurable expenditures) } \\
\hline & (1) & $(2)$ & $(3)$ \\
\hline retired head & & $\begin{array}{l}-0.28705 \\
(-16.81)^{* * *}\end{array}$ & $\begin{array}{l}-0.17335 \\
(-12.79)^{* * *}\end{array}$ \\
\hline age $50 *$ ret & & $\begin{array}{l}-0.05788 \\
(-2.03)^{* *}\end{array}$ & $\begin{array}{l}-0.04552 \\
(-2.05)^{* *}\end{array}$ \\
\hline age $55 *$ ret & & $\begin{array}{l}-0.01184 \\
(-0.51)\end{array}$ & $\begin{array}{l}-0.04042 \\
(-2.26)^{* *}\end{array}$ \\
\hline age $60 *$ ret & & $\begin{array}{l}0.08166 \\
(3.46)^{* * *}\end{array}$ & $\begin{array}{l}0.00806 \\
(0.44)\end{array}$ \\
\hline age $63 *$ ret & & $\begin{array}{l}0.07385 \\
(2.60)^{* * *}\end{array}$ & $\begin{array}{l}0.01986 \\
(0.92)\end{array}$ \\
\hline year 1988 & $\begin{array}{l}-0.02123 \\
(-6.12)^{* * *}\end{array}$ & $\begin{array}{l}-0.02364 \\
(-6.82)^{* * *}\end{array}$ & $\begin{array}{l}0.00507 \\
(1.78)\end{array}$ \\
\hline year 1993 & $\begin{array}{l}0.05005 \\
(13.72)^{* * *}\end{array}$ & $\begin{array}{l}0.05058 \\
(13.85)^{* * *}\end{array}$ & $\begin{array}{l}0.06591 \\
(23.39)^{* * *}\end{array}$ \\
\hline year 1998 & $\begin{array}{l}-0.02033 \\
(-7.24)^{* * *}\end{array}$ & $\begin{array}{l}-0.01885 \\
(-6.72)^{* * *}\end{array}$ & $\begin{array}{l}-0.03815 \\
(-17.43)^{* * *}\end{array}$ \\
\hline $\ln ($ eq.adults $)$ & & & $\begin{array}{l}0.43315 \\
(51.69)^{* * *}\end{array}$ \\
\hline nkids & & & $\begin{array}{l}-0.0414 \\
(-18.68)^{* * *}\end{array}$ \\
\hline female head & & & $\begin{array}{l}-0.04707 \\
(-10.15)^{* * *}\end{array}$ \\
\hline couple & & & $\begin{array}{l}0.13865 \\
(19.16)^{* * *}\end{array}$ \\
\hline self-empl. & & & $\begin{array}{l}0.02767 \\
(4.42)^{* * *}\end{array}$ \\
\hline farmer & & & $\begin{array}{l}-0.27231 \\
(-27.85)^{* * *}\end{array}$ \\
\hline unemployed & & & $\begin{array}{l}-0.40484 \\
(-53.70)^{* * *}\end{array}$ \\
\hline house size & & & $\begin{array}{l}0.00361 \\
(77.26)^{* * *}\end{array}$ \\
\hline city size & & & $\begin{array}{l}0.04341 \\
(32.71)^{* * *}\end{array}$ \\
\hline Constant & $\begin{array}{l}9.95015 \\
(290.43)^{* * *}\end{array}$ & $\begin{array}{l}9.98053 \\
(290.49)^{* * *}\end{array}$ & $\begin{array}{l}9.62871 \\
(328.93)^{* * *}\end{array}$ \\
\hline $\begin{array}{l}\text { \# Obs. } \\
\text { Adj. } R^{2}\end{array}$ & $\begin{array}{l}201826 \\
0.2\end{array}$ & $\begin{array}{l}201826 \\
0.21\end{array}$ & $\begin{array}{l}201826 \\
0.49\end{array}$ \\
\hline
\end{tabular}




\subsection{Home production}

The empirical specification in this section replicates to a large degree the one in the preceding section and is as follows:

$$
\ln h p_{h t}=\sum_{a_{l}}^{a_{h}} \beta_{a} a g e_{h a}+\sum_{k=1}^{K} \eta_{k} Z_{h k}+\delta \cdot \operatorname{ret}_{h}+\sum_{a_{l}=50}^{a_{h}=65} \zeta \cdot \operatorname{ret}_{h} \cdot \operatorname{age}_{h a}+\epsilon_{h t}
$$

where the dependent variable is household home production time per day, $h p$. I make use of the richer set of household demographics available in this data set, e.g. education and home ownership, and control for the weekday at which time use was recorded in the diary.

The results are shown in Table 2. The estimated coefficient for the retirement dummy is consistent with the hypothesis that households substitute consumer expenses in part by increased home production in retirement. The increase is in the magnitude of 82 minutes per day, roughly an increase of $33 \%$, and the coefficient is highly significant. The interacted age-retirement dummies are not significant, so there is no indication of age-specific retirement effects. Figure 7 illustrates the estimated age profiles by retirement status. The age profile of not retired households is increasing until age 60-65, and falls rapidly after age 75 , probably due to functional limitations and the deterioration of health conditions. For households with a retired head, home production time increases discontinuously at age $50 .{ }^{12}$ Thus, the drop in consumer expenses is met by a significant and discontinuous increase in home production.

Figure 7: Age profiles of home production by retirement status

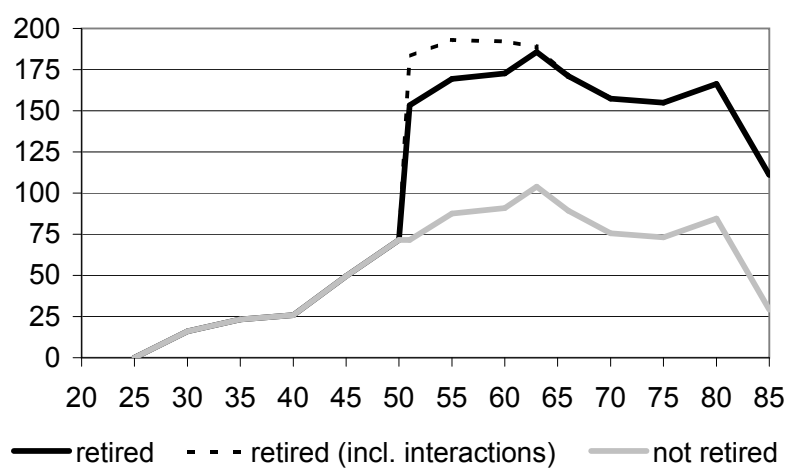

\footnotetext{
${ }^{12}$ The dotted line shows home production of retired heads if one additionally considers the (not significant) coefficients for the age-retirement interactions.
} 
Table 2: Regression results: Home Production

\begin{tabular}{|c|c|c|c|}
\hline \multicolumn{4}{|c|}{ dependent variable: household home production time (in mins per day) } \\
\hline retired head & $\begin{array}{l}81.770 \\
(5.20)^{* * *}\end{array}$ & $\ln ($ eq.Adults $)$ & $\begin{array}{l}44.298 \\
(4.53)^{* * *}\end{array}$ \\
\hline age $50 *$ ret & $\begin{array}{l}29.777 \\
(0.86)\end{array}$ & nkids0-5 & $\begin{array}{l}143.485 \\
(26.80)^{* * *}\end{array}$ \\
\hline age $55 *$ ret & $\begin{array}{l}23.731 \\
(0.94)\end{array}$ & nkids6-18 & $\begin{array}{l}35.765 \\
(9.99)^{* * *}\end{array}$ \\
\hline age60 $*$ ret & $\begin{array}{l}19.344 \\
(0.82)\end{array}$ & female head & $\begin{array}{l}31.770 \\
(5.15)^{* * *}\end{array}$ \\
\hline age63*ret & $\begin{array}{l}3.257 \\
(0.11)\end{array}$ & couple & $\begin{array}{l}223.881 \\
(25.73)^{* * *}\end{array}$ \\
\hline age 25 & $\begin{array}{l}21.822 \\
(1.52)\end{array}$ & self-empl. & $\begin{array}{l}-75.827 \\
(10.29)^{* * *}\end{array}$ \\
\hline age30 & $\begin{array}{l}37.928 \\
(2.80)^{* * *}\end{array}$ & unempl. & $\begin{array}{l}86.207 \\
(9.44)^{* * *}\end{array}$ \\
\hline age 35 & $\begin{array}{l}45.127 \\
(3.30)^{* * *}\end{array}$ & house size & $\begin{array}{l}-0.003 \\
(0.04)\end{array}$ \\
\hline age 40 & $\begin{array}{l}47.655 \\
(3.49)^{* * *}\end{array}$ & app. Owner & $\begin{array}{l}1.191 \\
(0.14)\end{array}$ \\
\hline age 45 & $\begin{array}{l}71.333 \\
(5.18)^{* * *}\end{array}$ & house owner & $\begin{array}{l}25.642 \\
(3.97)^{* * *}\end{array}$ \\
\hline age 50 & $\begin{array}{l}93.359 \\
(6.81)^{* * *}\end{array}$ & garden & $\begin{array}{l}41.412 \\
(7.75)^{* * *}\end{array}$ \\
\hline age 55 & $\begin{array}{l}109.374 \\
(7.74)^{* * *}\end{array}$ & schoolyears & $\begin{array}{l}1.497 \\
(2.05)^{* *}\end{array}$ \\
\hline age60 & $\begin{array}{l}112.748 \\
(6.08) * * *\end{array}$ & Tuesday & $\begin{array}{l}-3.993 \\
(0.55)\end{array}$ \\
\hline age63 & $\begin{array}{l}125.775 \\
(4.59)^{* * *}\end{array}$ & Wednesday & $\begin{array}{l}2.135 \\
(0.28)\end{array}$ \\
\hline age66 & $\begin{array}{l}111.173 \\
(5.35)^{* * *}\end{array}$ & Thursday & $\begin{array}{l}2.958 \\
(0.39)\end{array}$ \\
\hline age70 & $\begin{array}{l}97.461 \\
(4.59)^{* * *}\end{array}$ & Friday & $\begin{array}{l}19.219 \\
(2.56)^{* *}\end{array}$ \\
\hline age 75 & $\begin{array}{l}94.936 \\
(4.35)^{* * *}\end{array}$ & Saturday & $\begin{array}{l}62.692 \\
(7.75)^{* * *}\end{array}$ \\
\hline age 80 & $\begin{array}{l}106.318 \\
(4.44)^{* * *}\end{array}$ & Sunday & $\begin{array}{l}-83.487 \\
(10.68)^{* * *}\end{array}$ \\
\hline age85 & $\begin{array}{l}51.029 \\
(1.59)\end{array}$ & central & $\begin{array}{l}2.009 \\
(0.41)\end{array}$ \\
\hline constant & $\begin{array}{l}54.985 \\
(3.60)^{* * *}\end{array}$ & east & $\begin{array}{l}3.132 \\
(0.53)\end{array}$ \\
\hline \# Obs. & 13548 & Adj. $R^{2}$ & 0.43 \\
\hline
\end{tabular}

Robust t statistics in parentheses. ${ }^{*},{ }^{* *},{ }^{* * *}$ significant at $10 \%, 5 \%, 1 \%$ 
The household characteristics have the expected signs: More home production is done in larger households, especially those with young children who require a large amount of care. Female headed and couple households spend more time on home production. The same applies to house and garden ownership which indicates a higher incentive in maintaining the home. The self-employed do less home production which corresponds with their higher spending, while unemployed people do more.

\subsection{What is produced at home?}

The detailed diary information on specific activities allows a decomposition of home production time into its components. In this section, I re-estimate equation (2) using specific productive activities instead of overall home production to show the predominant activities that retired households engage in (see Table 3). Retired households engage significantly more in cooking and preparing meals, paperwork and gardening. The latter might be to some extent more a hobby than home production, so I re-estimated Table 2 excluding gardening from the list of home production activities. This reduces the retirement effect to 66 minutes per day, as can be seen from the first column in Table 3, labeled HP2.

Table 3: Regression results: Home Production, disaggregated by activities

\begin{tabular}{l|llllllll}
\hline & HP2 & cooking & washing & clean. & garden. & shopping & paperw. & DIY \\
\hline retired & 66.01 & 16.97 & 7.00 & 5.81 & 11.96 & 1.38 & 7.02 & 3.22 \\
head & $(4.7)^{* * *}$ & $(3.0)^{* * *}$ & $(1.6)$ & $(1.5)$ & $(2.6)^{* * *}$ & $(0.5)$ & $(2.2)^{* *}$ & $(0.9)$ \\
\hline age50 & 13.68 & -0.80 & -12.46 & -11.17 & 10.55 & 11.83 & 5.61 & -9.66 \\
*ret & $(0.4)$ & $(0.1)$ & $(1.7)^{*}$ & $(1.7)^{*}$ & $(1.0)$ & $(2.1)^{* *}$ & $(0.7)$ & $(1.1)$ \\
age55 & 8.29 & -17.97 & -16.05 & -4.93 & 19.79 & 2.07 & -0.18 & 26.12 \\
*ret & $(0.4)$ & $(2.2)^{* *}$ & $(2.7)^{* * *}$ & $(0.8)$ & $(2.1)^{* *}$ & $(0.5)$ & $(0.0)$ & $(3.1)^{* * *}$ \\
age60 & 17.89 & -11.04 & -4.67 & -3.59 & 1.17 & -1.57 & -0.87 & 19.87 \\
$*$ ret & $(0.9)$ & $(1.3)$ & $(0.8)$ & $(0.7)$ & $(0.2)$ & $(0.4)$ & $(0.2)$ & $(2.6)^{* * *}$ \\
age63 & 2.74 & 9.10 & -3.21 & 9.90 & -0.88 & 2.98 & -4.61 & 11.68 \\
$*$ ret & $(0.1)$ & $(1.0)$ & $(0.4)$ & $(1.9)^{*}$ & $(0.1)$ & $(0.7)$ & $(0.9)$ & $(2.3)^{* *}$ \\
\hline
\end{tabular}

Robust t statistics in parentheses. ${ }^{*},{ }^{* *},{ }^{* * *}$ significant at $10 \%, 5 \%, 1 \%$. The regressions in this table include the same covariates as those in Table 2.

\section{Conclusions}

In this paper, I have used repeated cross sections of a large expenditure survey spanning the period 1978 until 1998 to study the changes in consumer expenditures at retirement. I find an expenditure drop of $17 \%$ of pre-retirement expenses on nondurable consumption in Germany. Similar magnitudes have been found 
in countries like the UK and the US, in spite of different pension systems and differential retirement incentives.

To investigate whether this expenditure drop causes a consumption drop of equal size, I analyze time use patterns at retirement, also on the basis of a large data set of repeated cross-sections. If households engage more actively in home production during retirement, then the expenditure drop is offset at least partially by increased consumption from home produced goods and services. The main finding is that there is a discontinuous increase in home production at retirement which amounts to an additional 82 minutes per day. More specifically, retired households increase their time spent mainly in the sector of cooking and preparing food, but they also engage more in doing paperwork and gardening. I do not find any evidence of increased time spent on shopping or maintenance works around the house. This significant increase indicates that households flexibly adapt to the change in time and money resources in retirement.

While these results are in line with those found for other countries, they are significantly larger in magnitude than those of the only other study on Germany. The expenditure drop is about double in size as the one found in Schwerdt (2005) who uses a small panel of retirement transitions in the SOEP, and an indirect consumption measure. Furthermore, I also find a larger increase in home production time of about 82 additional minutes per day.

The results point towards a similar conclusion for all countries studied so far: The retirement consumption puzzle cannot be explained by only one of the factors detailed in section 2, but rather by a combination of all explanatory factors. Substitution of market goods by increased home production is one of them.

\section{References}

Aguiar, M. and E. Hurst (2005). Consumption vs. expenditure. Journal of Political Economy 113(5), 919-948.

Banks, J., R. Blundell, and S. Tanner (1998). Is there a retirement-savings puzzle? American Economic Review 88(4), 769-788.

Berkel, B. and A. Börsch-Supan (2004). Pension reform in germany: The impact on retirement decisions. Finanzarchiv 60(3), 393-421.

Bernheim, D. B., J. Skinner, and S. Weinberg (2001). What accounts for the variation in retirement wealth among US households? American Economic Review 91(4), 832-857.

Börsch-Supan, A., R. Schnabel, S. Kohnz, and G. Mastrobuoni (2004). Micromodeling of retirement decisions in germany. In J. Gruber and D. A. Wise (Eds.), Social Security Programs and Retirement Around the World, pp. 285-343. Chicago: The University of Chicago Press. 
Christensen, M. L. (2004). Demand patterns around retirement: Evidence from spanish panel data. unpublished.

Deaton, A. (2000). The Analysis of Household Surveys. Baltimore: Johns Hopkins University Press.

Deaton, A. and C. Paxson (1994). Intertemporal choice and inequality. Journal of Political Economy 102(4330), 437-467.

Dilnot, A., R. Disney, P. Johnson, and E. Whitehouse (1994). Pensions Policy in the UK: An Economic Analysis. London: IFS Report No. 45.

Hamermesh, D. S. (1984). Consumption during retirement: The missing link in the life cycle. Review of Economics and Statistics 66(1), 1-7.

Hurd, M. and S. Rohwedder (2003). The retirement-consumption puzzle: Anticipated and actual declines in spending at retirement. NBER Working Paper 9586.

Hurd, M. D. and S. Rohwedder (2005). Changes in consumption and activities in retirement. Michigan Retirement Research Center 2005-096.

Laitner, J. and D. Silverman (2005). Estimating life cycle parameters from consumption behavior at retirement. NBER Working Paper 11163.

Miniaci, R., C. Monfardini, and G. Weber (2003). Is there a retirement consumption puzzle in italy? IFS Working Paper W03/14.

Modigliani, F. and R. Brumberg (1954). Utility analysis and the consumption function: An interpretation of cross-section data. In K. Kurihara (Ed.), Post-Keynesian Economics. New Brunswick: Rutgers University Press.

Schwerdt, G. (2005). Why does consumption fall at retirement? evidence from germany. Economics Letters 89(3), 300-305.

Smith, S. (2004). Can the retirement consumption puzzle be solved? IFS Working Paper W04/0\%. 


\section{Discussion Paper Series}

Mannheim Research Institute for the Economics of Aging Universität Mannheim

To order copies, please direct your request to the author of the title in question.

\begin{tabular}{|c|c|c|c|}
\hline Nr. & Autoren & Titel & Jahr \\
\hline $107-06$ & Barbara Berkel & $\begin{array}{l}\text { Retirement Age and Preretirement in German } \\
\text { Administrative Data }\end{array}$ & 06 \\
\hline $108-06$ & $\begin{array}{l}\text { Hans-Martin von } \\
\text { Gaudecker } \\
\text { Carsten Weber }\end{array}$ & $\begin{array}{l}\text { Mandatory Unisex Policies and Annuity Pricing: } \\
\text { Quasi-Experimental Evidence from Germany }\end{array}$ & 06 \\
\hline $109-06$ & Daniel Schunk & $\begin{array}{l}\text { The German SAVE Survey: Documentation and } \\
\text { Methodology }\end{array}$ & 06 \\
\hline $110-06$ & Barbara Berkel & $\begin{array}{l}\text { THE EMU and German Cross Border Portfolio } \\
\text { Flows }\end{array}$ & 06 \\
\hline $111-06$ & Martin Salm & $\begin{array}{l}\text { Can subjective mortality expectations and stated } \\
\text { preferences explain varying consumption and } \\
\text { saving behaviors among the elderly? }\end{array}$ & 06 \\
\hline $112-06$ & $\begin{array}{l}\text { Daniel Houser, } \\
\text { Daniel Schunk, } \\
\text { Joachim Winter }\end{array}$ & Trust Games Measure Trust & 06 \\
\hline $113-06$ & $\begin{array}{l}\text { Hanming Fang, } \\
\text { Michael Keane, } \\
\text { Ahmed Khwaja, } \\
\text { Martin Salm, } \\
\text { Dan Silverman }\end{array}$ & $\begin{array}{l}\text { Testing the Mechanisms of Structural Models: } \\
\text { The Case of the Mickey Mantle Effect }\end{array}$ & 06 \\
\hline $114-06$ & $\begin{array}{l}\text { Axel Börsch-Supan, } \\
\text { Anette Reil-Held, } \\
\text { Daniel Schunk }\end{array}$ & $\begin{array}{l}\text { Das Sparverhalten deutscher Haushalte: Erste } \\
\text { Erfahrungen mit der Riester-Rente }\end{array}$ & 06 \\
\hline $115-07$ & $\begin{array}{l}\text { Karsten Hank, } \\
\text { Barbara Schaan }\end{array}$ & $\begin{array}{l}\text { Cross-National Variations in the Correlation } \\
\text { between Frequency of Prayer and Health } \\
\text { among Older Europeans }\end{array}$ & 07 \\
\hline $116-07$ & Stephanie Stuck & $\begin{array}{l}\text { Informelle Arbeit älterer Frauen und Männer in } \\
\text { Europa }\end{array}$ & 07 \\
\hline $117-07$ & $\begin{array}{l}\text { Axel Börsch-Supan, } \\
\text { Anette Reil-Held, } \\
\text { Christina B. Wilke }\end{array}$ & $\begin{array}{l}\text { Zur Sozialversicherungsfreiheit der } \\
\text { Entgeltumwandlung }\end{array}$ & 07 \\
\hline $118-07$ & Martin Salm & $\begin{array}{l}\text { The Effect of Pensions on Longevity: Evidence } \\
\text { from Union Army Veterans }\end{array}$ & 07 \\
\hline $120-07$ & Melanie Lührmann & $\begin{array}{l}\text { Consumer Expenditures and Home Production } \\
\text { at Retirement - New Evidence from Germany }\end{array}$ & 07 \\
\hline
\end{tabular}

